OPEN ACCESS

Edited by:

Marilena Kampa,

University of Crete, Greece

Reviewed by:

Richard T. Premont,

Harrington Discovery Institute,

United States

Ira Driscoll,

University of Wisconsin-Milwaukee,

United States

*Correspondence:

Daniela Grassi

dada.grassi@gmail.com;

daniela.grassi@universidadeuropea.es

Specialty section:

This article was submitted to

Molecular and Structural

Endocrinology,

a section of the journal

Frontiers in Endocrinology

Received: 15 May 2020

Accepted: 02 July 2020

Published: 07 August 2020

Citation:

Llorente $R$, Marraudino $M$, Carrillo $B$

Bonaldo B, Simon-Areces J, Abellanas-Pérez P, Rivero-Aguilar $M$

Fernandez-Garcia JM, Pinos $H$,

Garcia-Segura LM, Collado $P$ and Grassi D (2020) G Protein-Coupled

Estrogen Receptor Immunoreactivity

Fluctuates During the Estrous Cycle

and Show Sex Differences in the

Amygdala and Dorsal Hippocampus.

Front. Endocrinol. 11:537.

doi: $10.3389 /$ fendo.2020.00537

\section{G Protein-Coupled Estrogen Receptor Immunoreactivity Fluctuates During the Estrous Cycle and Show Sex Differences in the Amygdala and Dorsal Hippocampus}

\author{
Ricardo Llorente ${ }^{1}$, Marilena Marraudino ${ }^{2}$, Beatriz Carrillo ${ }^{3,4}$, Brigitta Bonaldo ${ }^{2}$, \\ Julia Simon-Areces ${ }^{5}$, Pedro Abellanas-Pérez ${ }^{1}$, Marina Rivero-Aguilar ${ }^{1}$, \\ Jose M. Fernandez-Garcia ${ }^{3,4}$, Helena Pinos ${ }^{3,4}$, Luis M. Garcia-Segura ${ }^{6,7}$, \\ Paloma Collado ${ }^{3,4}$ and Daniela Grassi ${ }^{1,3,4,6,7 *}$
}

${ }^{1}$ Department of Preclinical Odontology, Universidad Europea de Madrid, Madrid, Spain, ${ }^{2}$ Department of Neuroscience Rita Levi Montalcini, Neuroscience Institute Cavalieri Ottolenghi, University of Turin, Turin, Italy, ${ }^{3}$ Department of Psychobiology, Universidad Nacional de Educación a Distancia (UNED), Madrid, Spain, ${ }^{4}$ Instituto Mixto de Investigación Escuela Nacional de Sanidad-UNED (IMIENS), Madrid, Spain, ${ }^{5}$ Department of Physiotherapy, Podology and Dance, Universidad Europea de Madrid, Madrid, Spain, ${ }^{6}$ Cajal Institute, CSIC, Madrid, Spain, ${ }^{7}$ Centro de Investigación Biomédica en Red Fragilidad y Envejecimiento Saludable (CIBERFES), Instituto de Salud Carlos III, Madrid, Spain

G protein-coupled estrogen receptor (GPER) in the amygdala and the dorsal hippocampus mediates actions of estradiol on anxiety, social recognition and spatial memory. In addition, GPER participates in the estrogenic regulation of synaptic function in the amygdala and in the process of adult neurogenesis in the dentate gyrus. While the distribution of the canonical estrogen receptors $\alpha$ and $\beta$ in the amygdala and dorsal hippocampus are well characterized, little is known about the regional distribution of GPER in these brain regions and whether this distribution is affected by sex or the stages of the estrous cycle. In this study we performed a morphometric analysis of GPER immunoreactivity in the posterodorsal medial, anteroventral medial, basolateral, basomedial and central subdivisions of the amygdala and in all the histological layers of CA1 and the dentate gyrus of the dorsal hippocampal formation. The number of GPER immunoreactive cells was estimated in these different structures. GPER immunoreactivity was detected in all the assessed subdivisions of the amygdaloid nucleus and dorsal hippocampal formation. The number of GPER immunoreactive cells was higher in males than in estrus females in the central $(P=0.001)$ and the posterodorsal medial amygdala $(P<0.05)$; higher in males than in diestrus females in the strata orients $(P<0.01)$ and radiatum-lacunosum-moleculare $(P<0.05)$ of CA1-CA3 and in the molecular layer of the dentate gyrus $(P<0.01)$; higher in diestrus females than in males in the basolateral amygdala $(P<0.05)$; higher in diestrus females than in estrus females in the central $(P<0.01)$, posterodorsal medial $(P<0.01)$ and basolateral amygdala $(P<0.01)$ and higher in estrus females than in diestrus females in the strata oriens $(P<0.05)$ and 
radiatum-lacunosum-moleculare $(P<0.05)$ of CA1-CA3 and in the molecular layer $(P<0.05)$ and the hilus of the dentate gyrus $(P<0.05)$. The findings suggest that estrogenic regulation of the amygdala and hippocampus through GPER may be different in males and in females and may fluctuate during the estrous cycle.

Keywords: amygdala, hippocampus, estrous cycle, limbic system, GPER, estrogens, estrus, diestrus

\section{INTRODUCTION}

The hippocampus and the amygdala are two anatomically and functionally interconnected brain regions that participate in the regulation of stress responses $(1,2)$, fear (3-5), emotions (6-8), learning $(9)$, and memory $(8,10)$. Both structures are integrated in the limbic system, which is altered in different pathological conditions, such as depression, anxiety, stress and schizophrenia, among others (11-20).

Some of the behaviors regulated by the hippocampus, the amygdala and their associated limbic structures are modulated by estradiol and testosterone (21-24) and are affected by sex (2528 ) and by the phases of the estrous cycle (29-33). This hormonal regulation may be mediated by the modification of synaptic activity and plasticity in both the hippocampus (33-38) and the amygdala $(29-31,39,40)$ and may represent a direct effect of testosterone and estradiol on these two brain structures, which express both androgen (41-43) and estrogen receptors (43-46).

Expression of classical estrogen receptors (ER) $\alpha$ and ER $\beta$ in the hippocampus and amygdala is well documented (4447). After the discovery of the membrane-associated G proteincoupled estrogen receptor 1 (GPER), several studies have also explored its localization and function in the brain (48). GPER protein has been localized in the developing (49-51) and adult rodent hippocampus (52-59). In addition, GPER mRNA (60-62) and protein $(63,64)$ have been also detected in the adult rodent amygdala. However, the possible changes in GPER distribution in function of sex and the ovarian cycle in the hippocampus and amygdala have not been explored. Therefore, in this study we have analyzed the possible differences in GPER immunoreactivity between male, diestrus and estrus females in different anatomical subdivisions of the rat hippocampus and amygdala.

\section{MATERIALS AND METHODS}

\section{Animals and Experimental Procedure}

Wistar albino male and female rats from our in-house colony were kept on a 12:12-h light-dark cycle and received food and water ad libitum. Animals were handled in accordance with the guidelines published in the "NIH Guide for the care and use of laboratory animals," the principles presented in the "Guidelines for the Use of Animals in Neuroscience Research" by the Society for Neuroscience, and following the European Union (2010/63/UE) and the Spanish legislation (L6/2013; RD53/2013). Experimental procedures were approved by our Institutional Animal Use and Care Committee (UNED, Madrid). Special care was taken to minimize animal suffering and to reduce the number of animals used to the minimum necessary.
Twenty-four adult rats 2 months old (eight males and 16 females) were separately housed in plastic cages. After 2 weeks of habituation and handling, the monitoring of the estrous cycle in female rats was performed during 7 days by vaginal smears $(65,66)$. At the day 7 , female rats were tested for the last vaginal smear in order to select the animals in estrus or diestrus (diestrus-2). Subsequently, all the animals, male and female, were deeply anesthetized with pentobarbital (Normon Veterinary Division, Madrid, Spain, $50 \mathrm{mg} / \mathrm{kg}$ ) and perfused through the left cardiac ventricle with $50 \mathrm{ml}$ of saline solution $(0.9 \% \mathrm{NaCl})$ followed by $250 \mathrm{ml}$ of fixative solution (4\% paraformaldehyde in $0.1 \mathrm{M}$ phosphate buffer, $\mathrm{pH}$ 7.4). Brains were quickly removed and immersed for $4-6 \mathrm{~h}$ at $4^{\circ} \mathrm{C}$ in the same fixative solution and then rinsed with phosphate buffer. Brains were placed for $72 \mathrm{~h}$ in a $30 \%$ sucrose solution in PBS, frozen in liquid isopentane at $-35^{\circ} \mathrm{C}$, and stored in a deep freezer at $-80^{\circ} \mathrm{C}$ until sectioning. Brains were serially cut in the coronal plane at $20 \mu \mathrm{m}$ thickness with a cryostat, obtaining 5 series of adjacent serial sections. In each series, each section was $100 \mu \mathrm{m}$ distant from the following one. The plane of sectioning was oriented to match the drawings corresponding to the transverse sections of the rat brain atlas of Paxinos and Watson (67). Sections were collected in multiwell plates with a cryoprotectant solution and kept at $-20^{\circ} \mathrm{C}$. Immunohistochemical assay for GPER was performed on different series.

\section{Immunohistochemistry}

The presence of GPER was detected by immunohistochemistry performed on free-floating sections according to the following steps. Before the reaction, the sections collected in the cryoprotectant solution were washed overnight at $4^{\circ} \mathrm{C}$ in PBS $0.1 \mathrm{M}, \mathrm{pH}$ 7.3-7.4. The following day, free floating sections were first washed for $30 \mathrm{~min}$ at room temperature in PBS $0.1 \mathrm{M}, \mathrm{pH}$ 7.3-7.4, containing $0.2 \%$ Triton $\mathrm{X}-100$ and $0.2 \%$ BSA. Sections were then treated for $10 \mathrm{~min}$ with a solution of PBS 0.1 M, pH 7.3-7.4, containing methanol/hydrogen peroxide (PBS/methanol 1:1 with $0.3 \%$ hydrogen peroxide) to quench endogenous peroxidase activity. Sections were washed for $30 \mathrm{~min}$ at room temperature in PBS $0.1 \mathrm{M}, \mathrm{pH} 7.3-7.4$, containing $0.2 \%$ Triton X-100 and $0.2 \%$ BSA and then incubated for $48 \mathrm{~h}$ at $4^{\circ} \mathrm{C}$ with a rabbit polyclonal GPER antibody (ABCAM, Cambridge, UK, reference ab39742) diluted 1:250 in 0.1 M PBS, pH 7.37.4, containing $0.2 \%$ Triton X-100, $0.2 \%$ BSA and $3 \%$ normal serum goat. A biotinylated goat anti-rabbit secondary antibody (Thermo scientific, Pierce, Rockford, IL, USA) was then used at a dilution of 1:300 for $120 \mathrm{~min}$ at room temperature. The antigen-antibody reaction was revealed by incubation with avidin-peroxidase complex (Thermo scientific, Pierce, Rockford, 

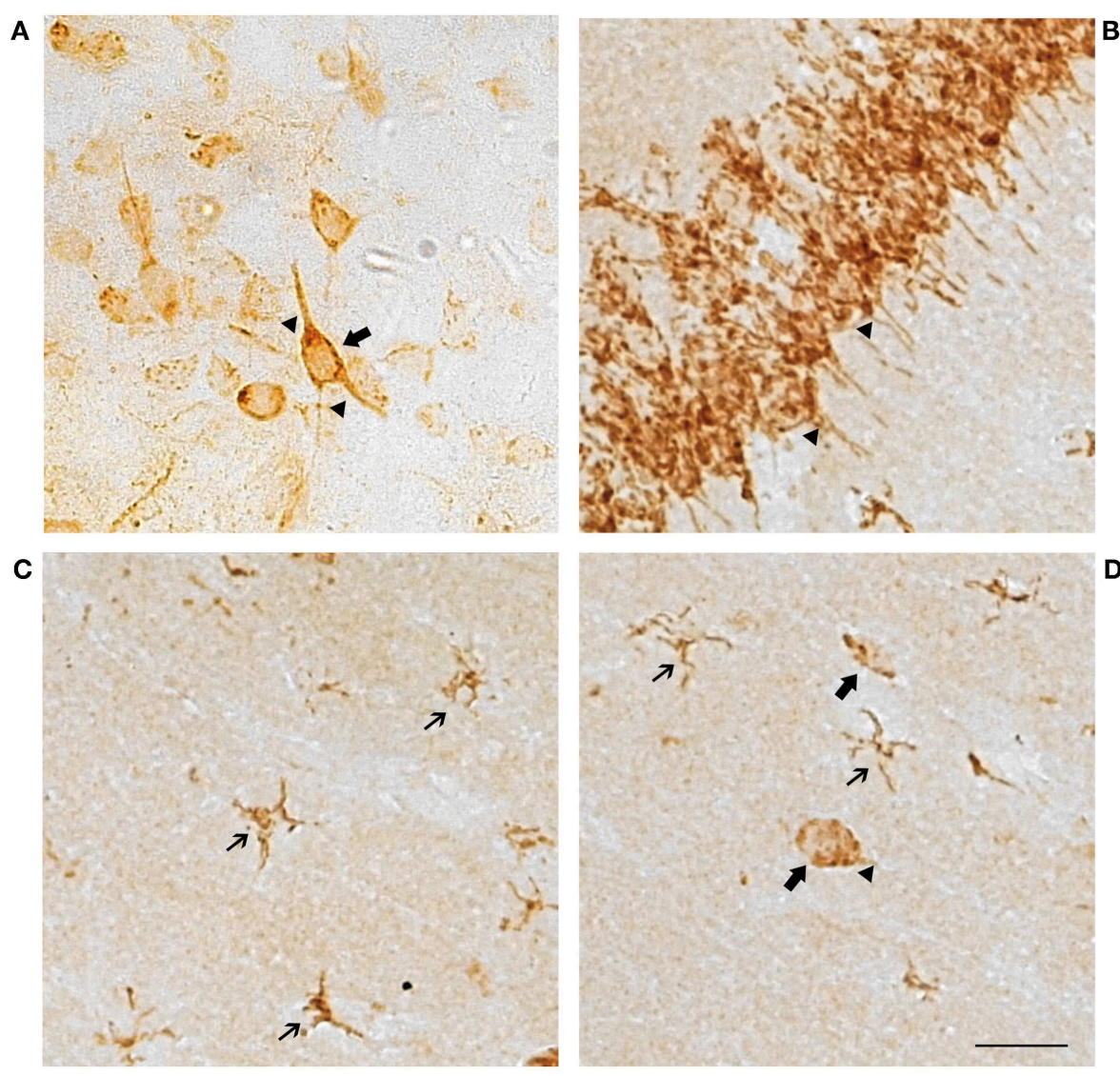

FIGURE 1 | Representative GPER immunostaining showing cell perikaryon and the primary processes labeling in neuronal and glial cells. (A) Amygdaloid nucleus and (B-D) Hippocampal formation. Scale bar $10 \mu \mathrm{m}$. Thin arrows, GPER immunoreactive cells with glial morphology. Large arrows, GPER immunoreactive cells with neuronal morphology. Arrowheads, immunoreactive neuronal processes.

IL, USA) for $90 \mathrm{~min}$. The peroxidase activity was visualized with a solution containing $0.187 \mathrm{mg} / \mathrm{mL} 3,3$ - diamino-benzidine (Sigma, Madrid, Spain) in PBS 0.1 M, pH 7.3-7.4. The sections were washed in the same buffer and collected on chromallum coated slides, air dried, cleared in xylene, and cover slipped with Depex (VWR International Eurolab, Barcelona, Spain) for quantitative analysis. One of each five consecutive sections was stained with $0.1 \%$ cresyl violet $(\mathrm{pH} 7.4)$ to facilitate the identification of the selected structures.

The GPER antibody used in the present study has been previously shown to recognize the full-length receptor protein in lysates of selected brain regions by Western blotting (68-72). Furthermore, immunostaining is abolished in rat brain sections when the GPER antibody is preincubated with the immunizing peptide (73). In agreement with our previous findings, GPER immunostaining was absent in rat brain sections preincubated with the GPER blocking peptide and when the first antibody was omitted.

\section{Morphometric Analysis}

The morphometric analysis of GPER immunoreactive cells was performed on coded sections without knowledge of the experimental group. The number of GPER positive cells was assessed in the amygdala and the dorsal hippocampus using two coded sections per animal. Sections selected for analysis corresponded to the following coordinates: bregma -2.8 to $-3.14 \mathrm{~mm}$ for the amygdaloid nucleus and bregma -2.8 to $-3.8 \mathrm{~mm}$ for the dorsal hippocampal formation (67). The following regions were considered for the morphometric analysis of GPER immunoreactive cells: (i), the posterodorsal medial (MePD), anteroventral medial (MeAV), basolateral (BLA), basomedial (BMA), and central (CeM) amygdala; (ii), the stratum oriens ( $\mathrm{SO}$ ), the stratum radiatum, analyzed together with the stratum lacunosum-moleculare (SRLM) and the stratum pyramidale (SP) in dorsal Ammon's horn and (iii), the stratum granulosum (SG), the stratum moleculare (SM) and the hilus in the dorsal dentate gyrus.

Data presented for each region are the sum of the number of GPER immunolabeled cells in two brain sections per rat. For the amygdala, all cells located within the anatomical borders of each subnuclei were considered for quantification. Cresyl violet stained sections were used as reference for the delimitation of the analyzed structures. Given the anatomical heterogeneity of the hippocampus, counts were limited to the dorsal hippocampus 
and performed separately in CA1-CA3 and in the dentate gyrus. Cells were counted in eight fields from CA1-CA3, four fields from the strata granulosum and moleculare of the dentate gyrus and two fields from the hilus. Each field had an average area of $9.63 \times$ $10^{3} \mu \mathrm{m}^{2}$ for the SO; $7.49 \times 10^{3} \mu \mathrm{m}^{2}$ for the SP; $23.76 \times 10^{3}$ $\mu \mathrm{m}^{2}$ for the SRLM; $6.52 \times 10^{3} \mu \mathrm{m}^{2}$ for the SG; $14.54 \times 10^{3}$ $\mu \mathrm{m}^{2}$ for the SM and $21.5 \times 10^{3} \mu \mathrm{m}^{2}$ for the hilus. Selected fields were acquired by a digital camera (Olympus DP25) connected to a Nikon eclipse E600 microscope using x40 and x20 objectives. All GPER positive cells showing a cell nucleus and located within the boundary of the selected anatomical regions were included in the analysis, regardless of differences in cell shape, size and level of immunostaining. As a note of caution, it is important to consider that our morphometric approach is not unbiased from possible differences among the experimental groups in the volume of the anatomical structures analyzed. Thus, it should be considered a semi-quantitative estimation of the number of GPER positive cells.

\section{Statistical Analysis}

Data were analyzed by one-way ANOVA followed by Bonferroni's post-hoc test, using the SPSS-17.0 software (SPSS Inc, Chicago, USA). A value of $P<0.05$ was considered statistically significant. Data are presented as the mean \pm SEM.

\section{RESULTS}

\section{Morphology of GPER Immunoreactive Cells}

Cells showed a punctiform staining in the brain sections incubated with the GPER antibody (Figure 1). The staining was cytoplasmic, and the cell nucleus was always negative. Numerous cells showed a clear neuronal morphology with cytoplasmic immunostaining in the cell perikaryon and the primary dendritic processes. Dendritic staining was particularly evident in the pyramidal neurons of the hippocampus (Figure 1B), but it was also detected in neurons from the other studied regions (Figure 1A). In addition to neurons, a population of GPER immunoreactive cells showed a small perikaryon surrounded by tiny cell processes, a morphology that is characteristic of glial cells. These cells with glial morphology were observed in all the studied brain regions and in some of these regions, such as in the stratum radiatum, the stratum lacunosum and the stratum moleculare of the hippocampus, they represented the vast majority of the immunoreactive cells (Figures 1C,D).

\section{GPER Positive Cells in the Amygdaloid Nucleus}

Representative examples of GPER immunoreactivity in the amygdala of male and female animals are shown in Figure 2. Qualitative observation of GPER immunopositive cells in the amygdaloid nucleus revealed some differences in the pattern of staining among the different experimental groups. These differences were confirmed by the morphometric analysis. ANOVA analysis revealed significant differences among experimental groups in the central amygdala (CeM) $\left[\mathrm{F}_{(2,13)}=23.10 ; P=0.001\right.$; Figure $\left.3 \mathrm{~A}\right]$, posterodorsal medial amygdala $(\mathrm{MePD})\left[\mathrm{F}_{(2,14)}=17.49 ; P=0.002\right.$; Figure $\left.3 \mathrm{~B}\right]$ and basolateral medial amygdala $(\mathrm{BLA})\left[\mathrm{F}_{(2,12)}=25.89 ; P=0.001\right.$; Figure 3C]. The post-hoc analysis revealed lower number of GPER immunopositive cells in estrus females that in males in the CeM $(P=0.001)$ and the MePD $(P<0.05)$ (Figures 3A,B). In contrast, females in diestrus showed a higher number of GPER immunoreactive cells than males in the BLA $(P<0.05)$ (Figure 2C). Moreover, estrus females showed a lower number of GPER immunoreactive cells than diestrus females in the CeM $(P<0.01)$, MePD $(P<0.01)$, and BLA $(P<0.01)$. No significant differences between the experimental groups were found in the basomedial (BMA) $\left[\mathrm{F}_{(2,12)}=0.828 ; P=0.38\right.$; Figure 3D] and anteroventral medial $(\mathrm{MeAV})$ amygdala $\left[\mathrm{F}_{(2,13)}=0.76\right.$; $P=0.41$; Figure 3E].

\section{GPER Positive Cells in the Dorsal Hippocampus}

Representative examples of GPER immunoreactive cells in the dorsal hippocampal formation are shown in Figure 4. ANOVA analysis showed significant differences in the stratum oriens (SO) $\left[\mathrm{F}_{(2,10)}=12.13 ; P=0.01\right.$; Figure 5A $]$ and the strata radiatum-lacunosum-moleculare $(\mathrm{SRLM})\left[\mathrm{F}_{(2,10)}=16.40 ; P=\right.$ 0.005 ; Figure 5B]. The post-hoc analysis revealed a significantly lower number of GPER immunoreactive cells in diestrus females compared to males in the SO $(P<0.01)$ and the SRLM $(P<$ $0.05)$. Moreover, diestrus females displayed also a lower number of GPER immunopositive cells than estrus female animals in the same regions: SO $(P<0.05)$ and SRLM $(P<0.05)$. In contrast, no significant differences among the experimental groups were detected in the stratum pyramidale $(\mathrm{SP})\left[\mathrm{F}_{(2,10)}=\right.$ $0.08 ; P=0.78$; Figure 5C].

Significant differences in the number of GPER immunoreactive cells among experimental groups were also detected in the dentate gyrus. Thus, ANOVA analysis showed significant differences in the stratum moleculare $(\mathrm{SM})\left[\mathrm{F}_{(2,10)}=\right.$ 12.69; $P=0.009$; Figure 5E $]$ and the hilus $\left[\mathrm{F}_{(2,10)}=10.89 ; P=\right.$ 0.013 ; Figure $5 \mathrm{~F}]$, but not in the stratum granulare $(\mathrm{SG})\left[\mathrm{F}_{(2,10)}\right.$ $=1.30 ; P=0.29$ Figure 5D]. Diestrus females showed a lower number of GPER immunoreactive cells than males in the SM $(P<0.01)$. In addition, diestrus females showed also a lower number of GPER immunopositive cells than estrus females in both the SM $(P<0.05)$ and the hilus $(P<0.05)$ (Figures 5E,F).

\section{DISCUSSION}

Previous studies have shown that GPER is widely distributed in the brain $(50,53,55,56,60,73)$. Indeed, GPER has been shown to be expressed by neurons, astrocytes and oligodendrocytes (56, $57,59,74-77)$ and GPER immunoreactivity has been detected by electron microscopy in both neuronal and glial profiles in the hippocampus (59), which is consistent with the detection of GPER immunoreactivity in cells with either neuronal or glial morphology in our study. Furthermore, we have detected a punctiform pattern of immunoreactivity that is absent in the cell nucleus, in agreement with the reported subcellular localization of GPER, either in the plasma membrane or in the endoplasmic reticulum and Golgi apparatus $(52,54,57,78-80)$. 
A

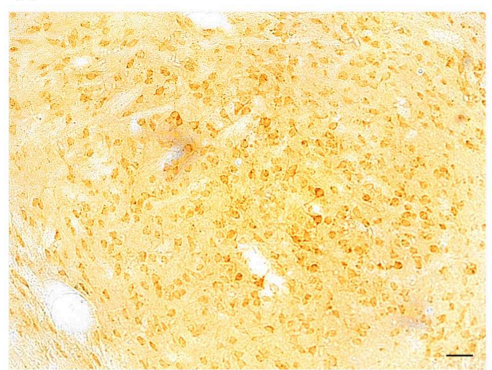

D

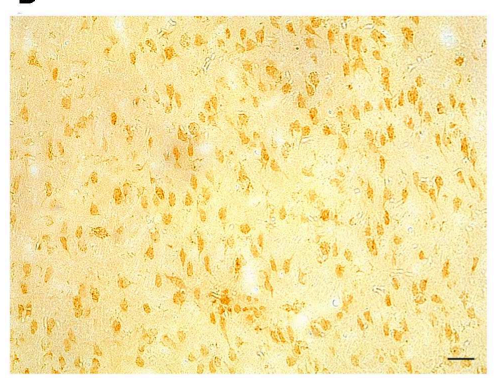

G

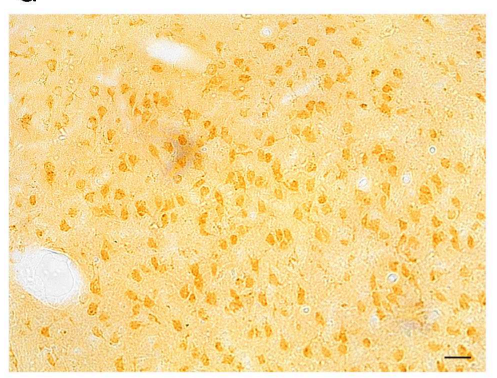

$\mathbf{J}$

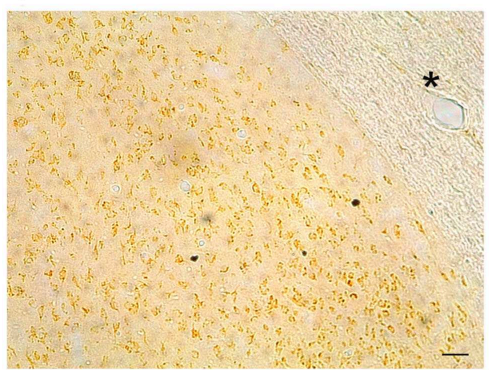

M

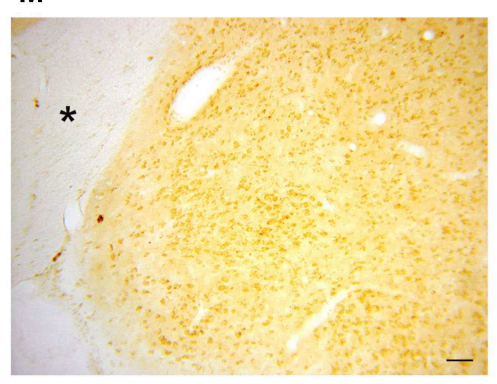

B

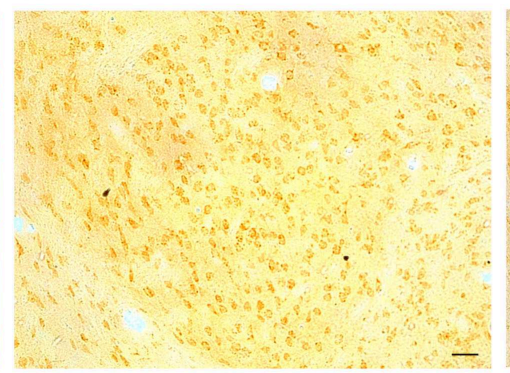

E

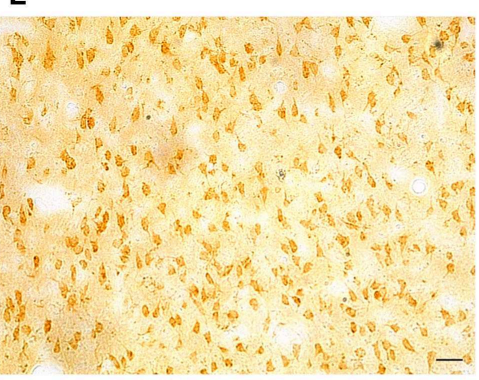

H

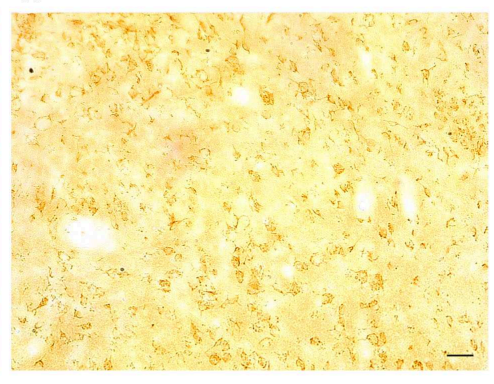

K

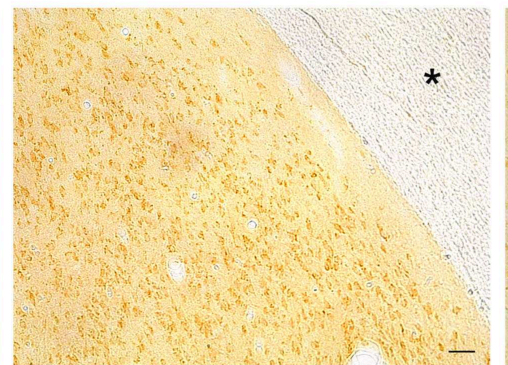

$\mathbf{N}$

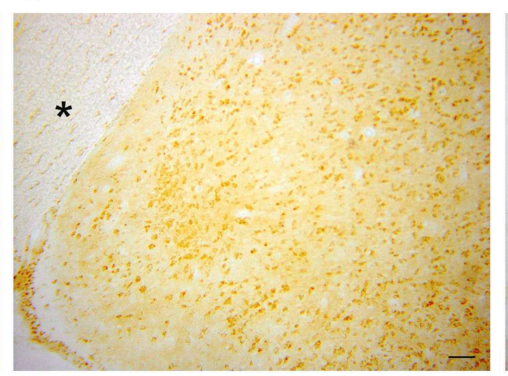

C

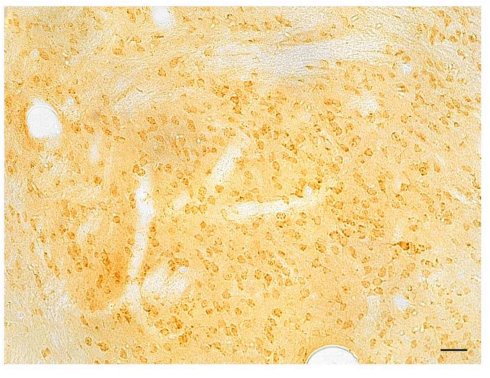

$\mathbf{F}$

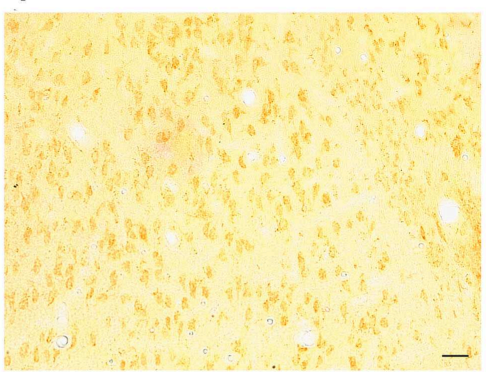

I

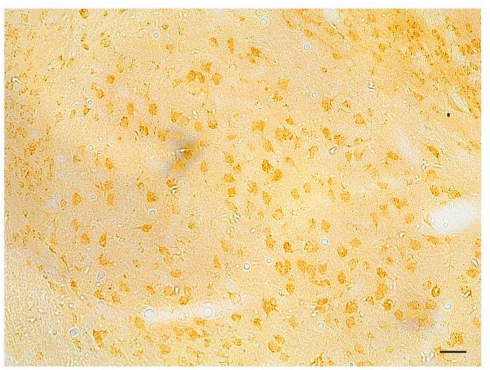

$\mathbf{L}$

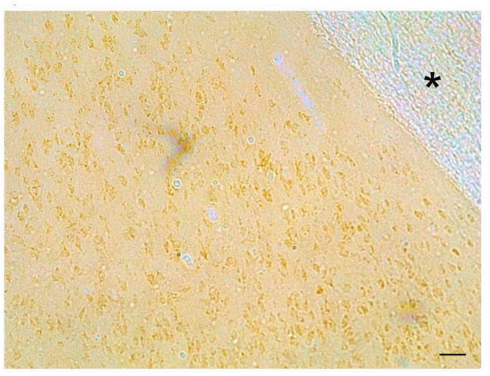

O

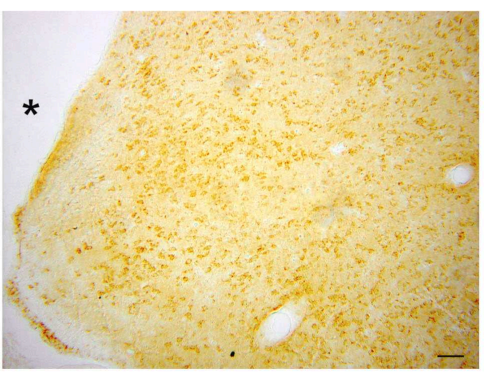

FIGURE 2 | Representative examples of GPER immunohistochemical localization in rat amygdaloid nucleus in male animals (left column; A,D,G,J,M) and in females during diestrus (central column; B,E,H,K,N) and estrus (right column; C,F,I,L,O). (A-C) Central amygdala (CeM), (D-F) Basolateral amygdala (BLA), (G-I) Basomedial amygdala (BMA), (J-L) Medial posterodorsal amygdala (MePD), (M-O) Medial anteroventral amygdala (MeAV). *Optic tract. Scale bar, $50 \mu \mathrm{m}$. 

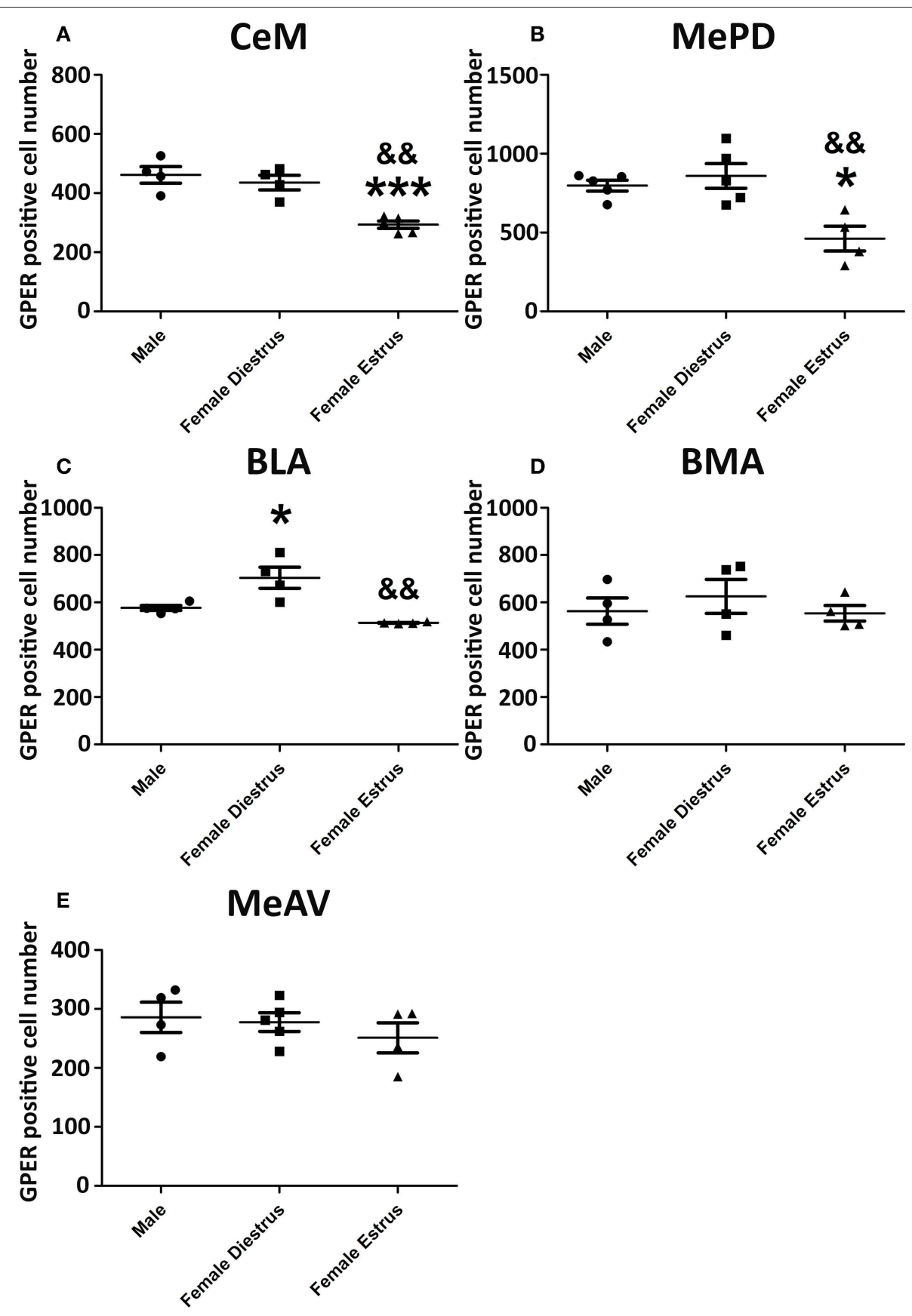

FIGURE 3 | Number of GPER immunoreactive cells in the amygdaloid nucleus of male, diestrus females and estrus female rats. (A) Central amygdala. (B) Medial posterodorsal amygdala. (C) Basolateral amygdala. (D) Basomedial amygdala. (E) Medial anteroventral amygdala. Data are represented as mean \pm SEM.

${ }^{*},{ }^{* \star}$ Significant differences $\left({ }^{*} p<0.05\right.$ and $\left.{ }^{* \star *} p<0.001\right)$ vs. male values. \&\& Significant differences $(p<0.01)$ vs. females in diestrus.

To explore possible changes in GPER immunoreactivity during the estrous cycle we performed a semi-quantitative analysis of the number of GPER immunoreactive cells. Although our findings need to be confirmed by unbiased stereology, they suggest that the immunoreactive levels of GPER fluctuate during the estrous cycle in the amygdala and the dorsal hippocampus with regional specificity. Thus, significant differences in the number of GPER immunoreactive cells are observed between estrus and diestrus in the central, posterodorsal medial and basolateral amygdala; in the stratum oriens and the strata radiatum-lacunosum-moleculare of the Ammon's horn and in the molecular layer and the hilus of the dentate gyrus. These fluctuations in the number of GPER immunoreactive cells between estrous cycle stages are associated with transient 


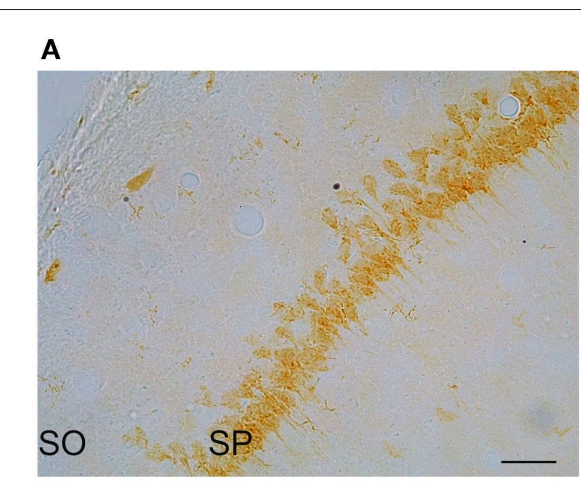

B

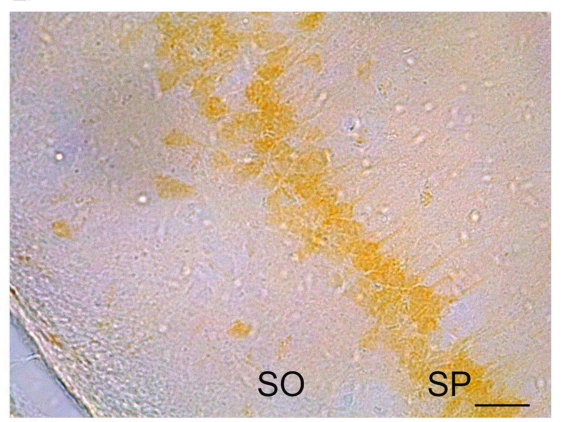

E

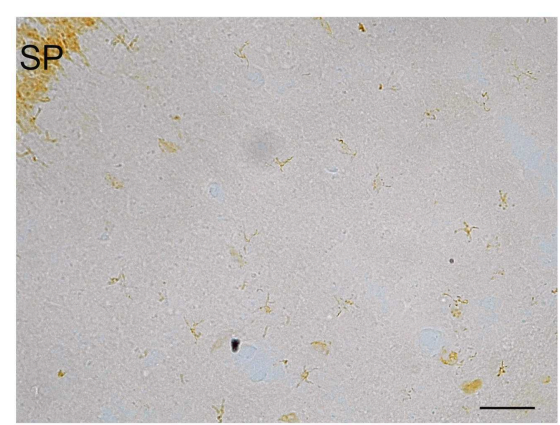

G

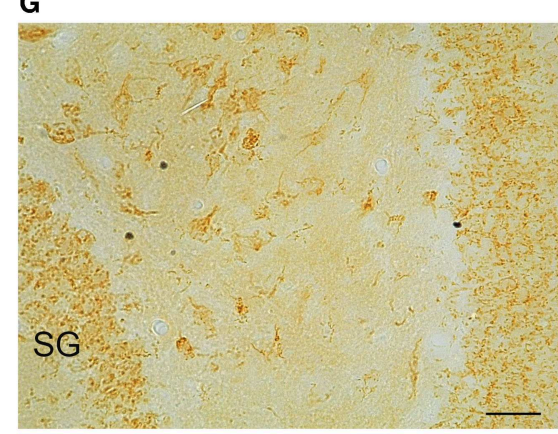

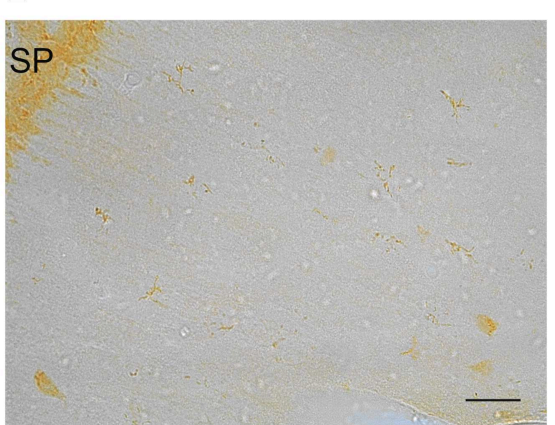

H

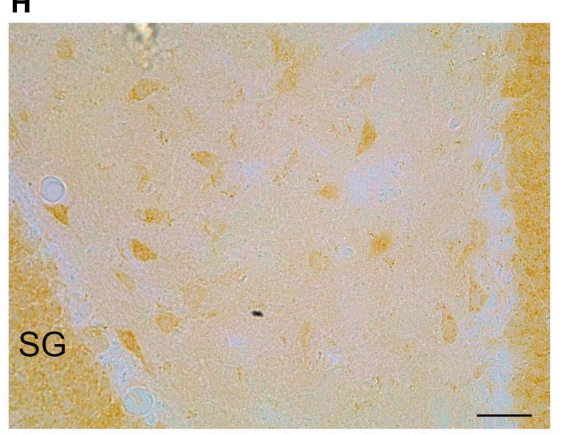

C

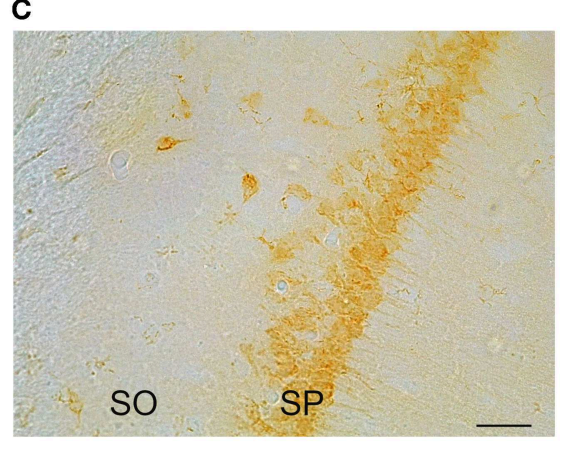

F

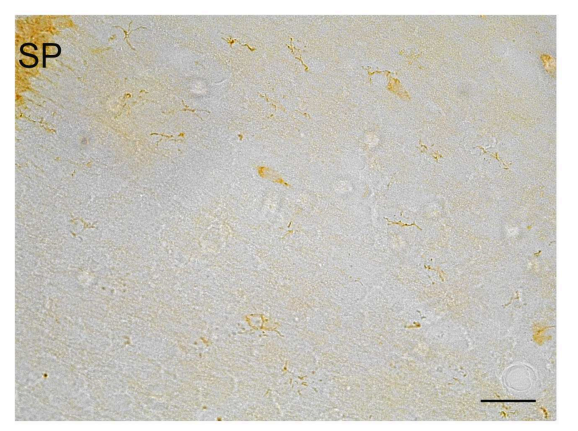

I

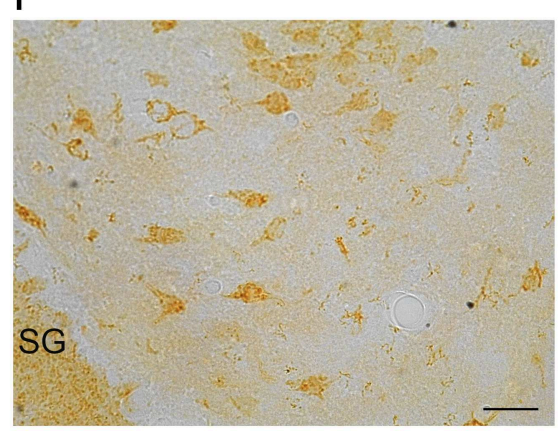

FIGURE 4 | Representative examples of GPER immunohistochemical localization in rat hippocampal formation in male animals (left column; A,D,G) and in females during diestrus (central column; B,E,H) and estrus (right column; C,F,I). (A-C) stratum oriens (SO) and stratum pyramidale (SP) in CA1, (D-F) stratum pyramidale (SP) and strata radiatum-lacunosum-moleculare in CA1. (G-I) Dentate gyrus, stratum granulare (SG) and hilus. Scale bar, $20 \mu \mathrm{m}$.

sex differences in GPER immunoreactivity that are also regionally specific.

Our findings extend the results of previous studies showing changes during the estrous cycle in the number of GPER immunoreactive axonal, dendritic and glial profiles in the mouse hippocampal formation (59). Sex differences in GPER expression have been also reported in primary hippocampal neurons (49). Another study has reported increased GPER mRNA levels in the amygdala of male hamster compared to females (60). In addition, differences in the mRNA levels of GPER between different estrous cycle days have been detected in other rat brain regions, such as the nucleus of the solitary tract, the ventrolateral medulla and the periaqueductal gray (81).

One of the limitations of the immunohistochemical analysis is that it cannot discriminate between full length functional receptors and other inactive forms. Therefore, we can only speculate on the possible functional significance of the fluctuation in the number of GPER immunoreactive cells in the amygdala and hippocampus during the estrous cycle and the associated sex differences. Differences in GPER levels may contribute to synaptic changes during the estrous cycle in the posterodorsal medial amygdala, the basolateral amygdala, the central amygdala and Ammon's horn (82-86) and may be also associated with the fluctuation in adult neurogenesis in the dentate gyrus of adult females in response to the cyclic changes in plasma estradiol levels (33). Specifically, GPER has been shown to be involved in the regulation of excitatory and inhibitory transmission in the basolateral amygdala $(61,63,86)$ and in the regulation of adult neurogeneis in the hippocampus (58). In addition, previous studies have shown that GPER in 

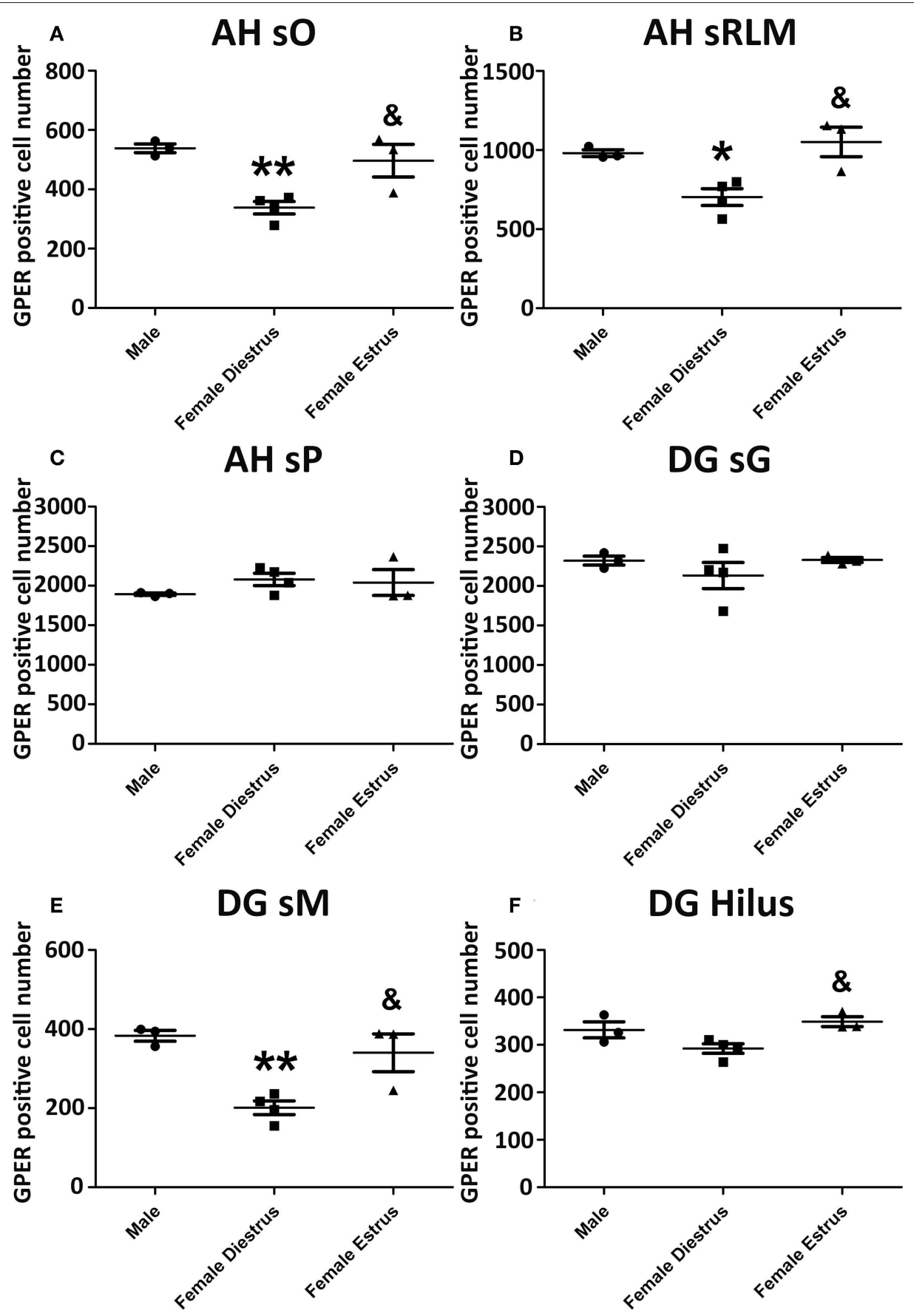

FIGURE 5 | Number of GPER immunoreactive cells in the in hippocampal formation of male, diestrus females and estrus female rats. (A) Ammon's horn, stratum oriens (SO). (B) Ammon's horn, strata radiatum-lacunosum-moleculare (SRLM). (C) Ammon's horn, stratum pyramidale (SP). (D) Dentate gyrus, stratum granulare (SG). (E) Dentate gyrus, stratum moleculare (SM). (F) Hilus. Data are represented as mean \pm SEM. ${ }^{\star},{ }^{* \star}$ Significant differences $\left({ }^{\star} p<0.05 ;{ }^{* \star} p<0.01\right)$ vs. male values. \& Significant difference $(p<0.05)$ vs. females in diestrus.

the basolateral amygdala mediates effects of estradiol on anxiety (64). Furthermore, GPER in the medial amygdala and the dorsal hippocampus participate in the modulation of social recognition by estradiol $(23,24,87)$. Moreover, GPER in the dorsal hippocampus also mediates effects of estradiol on object recognition and spatial memory (23, 24, 87-90). Therefore, the observed modifications in GPER immunoreactivity in the amygdala and hippocampus may affect the actions of estradiol on these structures to regulate anxiety, social recognition, object recognition and spatial memory. 


\section{DATA AVAILABILITY STATEMENT}

The raw data supporting the conclusions of this article will be made available by the authors, without undue reservation.

\section{ETHICS STATEMENT}

The animal study was reviewed and approved by Universidad Nacional de Educación a Ditancia (UNED) bioethics comitee in compliance with the Spanish Royal Decree 53/2013 and the European Directive 2010/63/EU.

\section{AUTHOR CONTRIBUTIONS}

DG, LG-S, and PC designed and supervised the experiments. JF-G, RL, MM, DG, BB, BC, JS-A, PA-P, MR-A, and HP

\section{REFERENCES}

1. Janak PH, Tye KM. From circuits to behaviour in the amygdala. Nature. (2015) 517:284-92. doi: 10.1038/nature14188

2. McEwen BS, Nasca C, Gray JD. Stress effects on neuronal structure: Hippocampus, Amygdala, and Prefrontal Cortex. Neuropsychopharmacology. (2016) 41:3-23. doi: 10.1038/npp.2015.171

3. Izquierdo I, Furini CR, Myskiw JC. Fear memory. Physiol Rev. (2016) 96:695750. doi: 10.1152/physrev.00018.2015

4. Maren S, Holmes A. Stress and fear extinction. Neuropsychopharmacology. (2016) 41:58-79. doi: 10.1038/npp.2015.180

5. Chaaya N, Battle AR, Johnson LR. An update on contextual fear memory mechanisms: transition between amygdala and hippocampus. Neurosci Biobehav Rev. (2018) 92:43-54. doi: 10.1016/j.neubiorev.2018. 05.013

6. LeDoux JE. Emotion circuits in the brain. Annu Rev Neurosci. (2000) 23:15584. doi: 10.1146/annurev.neuro.23.1.155

7. Catani M, Dell'acqua F, Thiebaut de Schotten M. A revised limbic system model for memory, emotion and behaviour. Neurosci Biobehav Rev. (2013) 37:1724-37. doi: 10.1016/j.neubiorev.2013.07.001

8. Yang Y, Wang JZ. From structure to behavior in basolateral amygdala-hippocampus circuits. Front Neural Circuits. (2017) 11:86. doi: $10.3389 /$ fncir.2017.00086

9. McDonald AJ, Mott DD. Functional neuroanatomy of amygdalohippocampal interconnections and their role in learning and memory. J Neurosci Res. (2017) 95:797-820. doi: 10.1002/jnr.23709

10. Richter-Levin G, Akirav I. Amygdala-hippocampus dynamic interaction in relation to memory. Mol Neurobiol. (2000) 22:11-20. doi: $10.1385 / \mathrm{MN}: 22: 1-3: 011$

11. Torrey EF, Peterson MR. Schizophrenia and the limbic system. Lancet. (1974) 2:942-6. doi: 10.1016/S0140-6736(74)91143-X

12. Herman JP, Ostrander MM, Mueller NK, Figueiredo H. Limbic system mechanisms of stress regulation: hypothalamo-pituitary-adrenocortical axis. Prog Neuropsychopharmacol Biol Psychiatry. (2005) 29:1201-13. doi: 10.1016/j.pnpbp.2005.08.006

13. Anthes E. Depression: a change of mind. Nature. (2014) 515:185-7. doi: $10.1038 / 515185 a$

14. Potvin S, Lungu O, Tikàsz A, Mendrek A. Abnormal effective frontolimbic connectivity during emotion processing in schizophrenia. Prog Neuropsychopharmacol Biol Psychiatry. (2017) 72:1-8. doi: 10.1016/j.pnpbp.2016.08.004

15. Sah P. Fear, anxiety, and the amygdala. Neuron. (2017) 96:1-2. doi: 10.1016/j.neuron.2017.09.013

16. Jimenez JC, Su K, Goldberg AR, Luna VM, Biane JS, Ordek G, et al. Anxiety cells in a hippocampal-hypothalamic circuit. Neuron. (2018) 97:670-83.e6. doi: 10.1016/j.neuron.2018.01.016 performed the experiments. RL and JS-A prepared the figures for publication. DG, RL, and LG-S wrote the first draft of the manuscript. All authors contributed to the article and approved the submitted version.

\section{FUNDING}

This study was supported by Ministero dell'Istruzione, dell'Università e della Ricerca, Italy (MIUR project Dipartimenti di Eccellenza 2018-2022) to Department of Neuroscience Rita Levi Montalcini, Agencia Estatal de Investigación, Spain (BFU2017-82754-R, PSI2017-86396-P), Centro de Investigación Biomédica en Red Fragilidad y Envejecimiento Saludable (CIBERFES), Instituto de Salud Carlos III, Madrid and Fondos FEDER, GRUPOS UCM-BSCH 951579. MM fellowship was generously granted by Prof. G. C. Bergui.

17. Malhi GS, Mann JJ. Depression. Lancet. (2018) 392:2299-312. doi: 10.1016/S0140-6736(18)31948-2

18. Vachon-Presseau E. Effects of stress on the corticolimbic system: implications for chronic pain. Prog Neuropsychopharmacol Biol Psychiatry. (2018) 87(Pt B):216-23. doi: 10.1016/j.pnpbp.2017.10.014

19. Fares J, Bou Diab Z, Nabha S, Fares Y. Neurogenesis in the adult hippocampus: history, regulation, and prospective roles. Int J Neurosci. (2019) 129:598-611. doi: 10.1080/00207454.2018.1545771

20. Seo D, Rabinowitz AG, Douglas RJ, Sinha R. Limbic response to stress linking life trauma and hypothalamus-pituitaryadrenal axis function. Psychoneuroendocrinology. (2019) 99:38-46. doi: 10.1016/j.psyneuen.2018.08.023

21. Fernandez SM, Lewis MC, Pechenino AS, Harburger LL, Orr PT, Gresack JE, et al. Estradiol-induced enhancement of object memory consolidation involves hippocampal ERK activation and membrane-bound estrogen receptors. J Neurosci. (2008) 28:8660-7. doi: 10.1523/JNEUROSCI.1968-08.2008

22. Fan L, Zhao Z, Orr PT, Chambers CH, Lewis MC, Frick KM. Estradiolinduced object memory consolidation in middle-aged female mice requires dorsal hippocampal extracellular signal-regulated kinase and phosphatidylinositol 3-kinase activation. J Neurosci. (2010) 30:4390-400. doi: 10.1523/JNEUROSCI.4333-09.2010

23. Paletta P, Sheppard PAS, Matta R, Ervin KSJ, Choleris E. Rapid effects of estrogens on short-term memory: possible mechanisms. Horm Behav. (2018) 104:88-99. doi: 10.1016/j.yhbeh.2018.05.019

24. Lymer JM, Sheppard PAS, Kuun T, Blackman A, Jani N, Mahbub S, et al. Estrogens and their receptors in the medial amygdala rapidly facilitate social recognition in female mice. Psychoneuroendocrinology. (2018) 89:30-8. doi: 10.1016/j.psyneuen.2017.12.021

25. Milad MR, Zeidan MA, Contero A, Pitman RK, Klibanski A, Rauch SL, et al. The influence of gonadal hormones on conditioned fear, extinction in healthy humans. Neuroscience. (2010) 168:652-8. doi: 10.1016/j.neuroscience.2010.04.030

26. Keiser AA, Turnbull LM, Darian MA, Feldman DE, Song I, Tronson NC. Sex differences in context fear generalization and recruitment of hippocampus and amygdala during retrieval. Neuropsychopharmacology. (2017) 42:397-407. doi: $10.1038 / n p p .2016 .174$

27. Koss WA, Frick KM. Sex differences in hippocampal function. J Neurosci Res. (2017) 95:539-62. doi: 10.1002/jnr.23864

28. Yagi S, Galea LAM. Sex differences in hippocampal cognition and neurogenesis. Neuropsychopharmacology. (2019) 44:200-13. doi: 10.1038/s41386-018-0208-4

29. Rasia-Filho AA, Haas D, de Oliveira AP, de Castilhos J, Frey R, Stein D, et al. Morphological and functional features of the sex steroid-responsive posterodorsal medial amygdala of adult rats. Mini Rev Med Chem. (2012) 12:1090-106. doi: 10.2174/138955712802762211 
30. Hirsch MM, Brusco J, Vaccaro T, Margis R, Moreira JE, Gottfried C, et al. Sex differences and estrous cycle changes in synaptic plasticity-related microRNA in the rat medial amygdala. Neuroscience. (2018) 379:405-14. doi: 10.1016/j.neuroscience.2018.03.035

31. Dalpian F, Rasia-Filho AA, Calcagnotto ME. Sexual dimorphism, estrous cycle and laterality determine the intrinsic and synaptic properties of medial amygdala neurons in rat. J Cell Sci. (2019) 132:jcs227793. doi: $10.1242 /$ jcs. 227793

32. Iqbal J, Tan ZN, Li MX, Chen HB, Ma B, Zhou X, et al. Estradiol alters hippocampal gene expression during the estrous cycle. Endocr Res. (2019) 45:84-101. doi: 10.1080/07435800.2019.1674868

33. Sheppard PAS, Choleris E, Galea LAM. Structural plasticity of the hippocampus in response to estrogens in female rodents. Mol Brain. (2019) 12:22. doi: 10.1186/s13041-019-0442-7

34. MacLusky NJ, Luine VN, Hajszan T, Leranth C. The 17alpha and 17beta isomers of estradiol both induce rapid spine synapse formation in the CA1 hippocampal subfield of ovariectomized female rats. Endocrinology. (2005) 146:287-93. doi: 10.1210/en.2004-0730

35. Mendez P, Garcia-Segura LM, Muller D. Estradiol promotes spine growth and synapse formation without affecting pre-established networks. Hippocampus. (2011) 21:1263-7. doi: 10.1002/hipo.20875

36. Atwi S, McMahon D, Scharfman H, MacLusky NJ. Androgen modulation of hippocampal structure and function. Neuroscientist. (2016) 22:46-60. doi: $10.1177 / 1073858414558065$

37. Murakami G, Hojo Y, Kato A, Komatsuzaki Y, Horie S, Soma M, et al. Rapid nongenomic modulation by neurosteroids of dendritic spines in the hippocampus: androgen, oestrogen and corticosteroid. J Neuroendocrinol. (2018) 30:e12561. doi: 10.1111/jne.12561

38. Luine V, Frankfurt M. Estrogenic regulation of memory: the first 50 years. Horm Behav. (2020) 121:104711. doi: 10.1016/j.yhbeh.2020.104711

39. Rasia-Filho AA, Dalpian F, Menezes IC, Brusco J, Moreira JE, Cohen RS. Dendritic spines of the medial amygdala: plasticity, density, shape, and subcellular modulation by sex steroids. Histol Histopathol (2012) 27:985-1011. doi: 10.14670/HH-27.985

40. Blume SR, Freedberg M, Vantrease JE, Chan R, Padival M, Record MJ, et al. Sex- and estrus-dependent differences in rat basolateral amygdala. J Neurosci. (2017) 37:10567-86. doi: 10.1523/JNEUROSCI.0758-17.2017

41. Sarkey S, Azcoitia I, Garcia-Segura LM, Garcia-Ovejero D, DonCarlos LL. Classical androgen receptors in non-classical sites in the brain. Horm Behav. (2008) 53:753-64. doi: 10.1016/j.yhbeh.2008.02.015

42. Moghadami S, Jahanshahi M, Sepehri H, Amini H. Gonadectomy reduces the density of androgen receptor-immunoreactive neurons in male rat's hippocampus: testosterone replacement compensates it. Behav Brain Funct. (2016) 12:5. doi: 10.1186/s12993-016-0089-9

43. Tozzi A, Durante V, Manca P, Di Mauro M, Blasi J, Grassi S, et al. Bidirectional synaptic plasticity is driven by sex neurosteroids targeting estrogen and androgen receptors in hippocampal CA1 pyramidal neurons. Front Cell Neurosci. (2019) 13:534. doi: 10.3389/fncel.2019.00534

44. Shughrue P, Scrimo P, Lane M, Askew R, Merchenthaler I. The distribution of estrogen receptor-beta mRNA in forebrain regions of the estrogen receptor-alpha knockout mouse. Endocrinology. (1997) 138:5649-52. doi: 10.1210/endo.138.12.5712

45. Shughrue PJ, Scrimo PJ, Merchenthaler I. Evidence for the colocalization of estrogen receptor-beta mRNA and estrogen receptor-alpha immunoreactivity in neurons of the rat forebrain. Endocrinology. (1998) 139:5267-70. doi: 10.1210/endo.139.12.6525

46. Mitra SW, Hoskin E, Yudkovitz J, Pear L, Wilkinson HA, Hayashi S, et al. Immunolocalization of estrogen receptor beta in the mouse brain: comparison with estrogen receptor alpha. Endocrinology. (2003) 144:2055-67. doi: 10.1210/en.2002-221069

47. Shughrue PJ, Merchenthaler I. Distribution of estrogen receptor beta immunoreactivity in the rat central nervous system. J Comp Neurol. (2001) 436:64-81. doi: 10.1002/cne.1054

48. Hadjimarkou MM, Vasudevan N. GPER1/GPR30 in the brain: Crosstalk with classical estrogen receptors and implications for behavior. J Steroid Biochem Mol Biol. (2018) 176:57-64. doi: 10.1016/j.jsbmb.2017.04.012
49. Ruiz-Palmero I, Ortiz-Rodriguez A, Melcangi RC, Caruso D, Garcia-Segura LM, Rune GM, et al. Oestradiol synthesized by female neurons generates sex differences in neuritogenesis. Sci Rep. (2016) 6:31891. doi: 10.1038/srep31891

50. Wang YX, Zhu L, Li LX, Xu HN, Wang HG, An D, et al. Postnatal expression patterns of estrogen receptor subtypes and choline acetyltransferase in different regions of the Papez circuit. Dev Neurosci. (2019) 41:203-11. doi: $10.1159 / 000502686$

51. Ruiz-Palmero I, Hernando M, Garcia-Segura LM, Arevalo MA. G proteincoupled estrogen receptor is required for the neuritogenic mechanism of $17 \beta$ estradiol in developing hippocampal neurons. Mol Cell Endocrinol. (2013) 372:105-15. doi: 10.1016/j.mce.2013.03.018

52. Funakoshi T, Yanai A, Shinoda K, Kawano MM, Mizukami Y. G proteincoupled receptor 30 is an estrogen receptor in the plasma membrane. Biochem Biophys Res Commun. (2006) 346:904-10. doi: 10.1016/j.bbrc.2006.05.191

53. Brailoiu E, Dun SL, Brailoiu GC, Mizuo K, Sklar LA, Oprea TI, et al. Distribution and characterization of estrogen receptor $\mathrm{G}$ protein-coupled receptor 30 in the rat central nervous system. J Endocrinol. (2007) 193:311-21. doi: $10.1677 /$ JOE-07-0017

54. Matsuda K, Sakamoto H, Mori H, Hosokawa K, Kawamura A, Itose M, et al. Expression and intracellular distribution of the $\mathrm{G}$ protein-coupled receptor 30 in rat hippocampal formation. Neurosci Lett. (2008) 441:94-9. doi: 10.1016/j.neulet.2008.05.108

55. Hazell GG, Yao ST, Roper JA, Prossnitz ER, O'Carroll AM, Lolait SJ. Localisation of GPR30, a novel G protein-coupled oestrogen receptor, suggests multiple functions in rodent brain and peripheral tissues. J Endocrinol. (2009) 202:223-36. doi: 10.1677/JOE-09-0066

56. Hammond R, Nelson D, Gibbs RB. GPR30 co-localizes with cholinergic neurons in the basal forebrain and enhances potassium-stimulated acetylcholine release in the hippocampus. Psychoneuroendocrinology. (2011) 36:182-92. doi: 10.1016/j.psyneuen.2010.07.007

57. Akama KT, Thompson LI, Milner TA, McEwen BS. Post-synaptic density95 (PSD-95) binding capacity of G-protein-coupled receptor 30 (GPR30), an estrogen receptor that can be identified in hippocampal dendritic spines. J Biol Chem. (2013) 288:6438-50. doi: 10.1074/jbc.M112.412478

58. Duarte-Guterman P, Lieblich SE, Chow C, Galea LA. Estradiol and GPER activation differentially affect cell proliferation but not GPER expression in the Hippocampus of adult female rats. PLoS ONE. (2015) 10:e0129880. doi: 10.1371/journal.pone.0129880

59. Waters EM, Thompson LI, Patel P, Gonzales AD, Ye HZ, Filardo EJ, et al. Gprotein-coupled estrogen receptor 1 is anatomically positioned to modulate synaptic plasticity in the mouse hippocampus. J Neurosci. (2015) 35:2384-97. doi: 10.1523/JNEUROSCI.1298-14.2015

60. Canonaco M, Giusi G, Madeo A, Facciolo RM, Lappano R, Canonaco A, et al. A sexually dimorphic distribution pattern of the novel estrogen receptor Gprotein-coupled receptor 30 in some brain areas of the hamster. J Endocrinol. (2008) 196:131-8. doi: 10.1677/JOE-07-0392

61. Yang R, Zhang B, Chen T, Zhang S, Chen L. Postpartum estrogen withdrawal impairs GABAergic inhibition and LTD induction in basolateral amygdala complex via down-regulation of GPR30. Eur Neuropsychopharmacol. (2017) 27:759-72. doi: 10.1016/j.euroneuro.2017.05.010

62. Li J, Rao D, Gibbs RB. Effects of cholinergic lesions and cholinesterase inhibitors on aromatase and estrogen receptor expression in different regions of the rat brain. Neuroscience. (2018) 384:203-13. doi: 10.1016/j.neuroscience.2018.05.033

63. Tian Z, Wang Y, Zhang N, Guo YY, Feng B, Liu SB, et al. Estrogen receptor GPR30 exerts anxiolytic effects by maintaining the balance between GABAergic and glutamatergic transmission in the basolateral amygdala of ovariectomized mice after stress. Psychoneuroendocrinology. (2013) 38:221833. doi: 10.1016/j.psyneuen.2013.04.011

64. Liu SB, Tian Z, Guo YY, Zhang N, Feng B, Zhao MG. Activation of GPR30 attenuates chronic pain-related anxiety in ovariectomized mice. Psychoneuroendocrinology. (2015) 53:94-107. doi: 10.1016/j.psyneuen.2014.12.021

65. Marcondes FK, Bianchi FJ, Tanno AP. Determination of the estrous cycle phases of rats: some helpful considerations. Braz J Biol. (2002) 62:609-14. doi: 10.1590/S1519-69842002000400008 
66. Hubscher $\mathrm{CH}$, Brooks DL, Johnson JR. A quantitative method for assessing stages of the rat estrous cycle. Biotech Histochem. (2005) 80:79-87. doi: 10.1080/10520290500138422

67. Paxinos G, Watson C. The Rat Brain in Stereotaxic Coordinates. 7th ed. New York, NY: Academic Press (2013).

68. Zhang Y, Xiao X, Zhang XM, Zhao ZQ, Zhang YQ. Estrogen facilitates spinal cord synaptic transmission via membrane-bound estrogen receptors: implications for pain hypersensitivity. J Biol Chem. (2012) 287:33268-81. doi: 10.1074/jbc.M112.368142

69. Broughton BR, Brait VH, Guida E, Lee S, Arumugam TV, Gardiner-Mann $\mathrm{CV}$, et al. Stroke increases g protein-coupled estrogen receptor expression in the brain of male but not female mice. Neurosignals. (2013) 21:229-39. doi: $10.1159 / 000338019$

70. Meseke M, Neumüller F, Brunne B, Li X, Anstötz M, Pohlkamp T, et al. Distal dendritic enrichment of HCN1 channels in hippocampal CA1 is promoted by estrogen, but does not require reelin. eNeuro. (2018) 5:ENEURO.025818.2018. doi: 10.1523/ENEURO.0258-18.2018

71. Wu Y, Feng D, Lin J, Qu Y, He S, Wang Y, et al. Downregulation of G protein coupled receptor 30 in the hippocampus attenuates the neuroprotection of estrogen in the critical period hypothesis. Mol Med Rep. (2018) 17:5716-25. doi: $10.3892 / \mathrm{mmr} .2018 .8618$

72. Zhao J, Bian C, Liu M, Zhao Y, Sun T, Xing F, et al. Orchiectomy and letrozole differentially regulate synaptic plasticity and spatial memory in a manner that is mediated by SRC-1 in the hippocampus of male mice. J Steroid Biochem Mol Biol. (2018) 178:354-68. doi: 10.1016/j.jsbmb.2018.02.007

73. Grassi D, Lagunas N, Pinos H, Panzica G, Garcia-Segura LM, Collado P. NADPH-diaphorase colocalizes with GPER and is modulated by the GPER agonist G1 in the supraoptic and paraventricular nuclei of ovariectomized female rats. Neuroendocrinology. (2017) 104:94-104. doi: 10.1159/0004 45190

74. Roque C, Mendes-Oliveira J, Baltazar G. G protein-coupled estrogen receptor activates cell type-specific signaling pathways in cortical cultures: relevance to the selective loss of astrocytes. J Neurochem. (2019) 149:27-40. doi: $10.1111 /$ jnc. 14648

75. Almey A, Cannell E, Bertram K, Filardo E, Milner TA, Brake WG. Medial prefrontal cortical estradiol rapidly alters memory system bias in female rats: ultrastructural analysis reveals membrane-associated estrogen receptors as potential mediators. Endocrinology. (2014) 155:4422-32. doi: 10.1210/en.2014-1463

76. Hirahara Y, Matsuda K, Gao W, Arvanitis DN, Kawata M, Boggs JM. The localization and non-genomic function of the membrane-associated estrogen receptor in oligodendrocytes. Glia. (2009) 57:153-65. doi: 10.1002/glia. 20742

77. Hirahara Y, Matsuda KI, Yamada H, Saitou A, Morisaki S, Takanami $\mathrm{K}$, et al. $\mathrm{G}$ protein-coupled receptor 30 contributes to improved remyelination after cuprizone-induced demyelination. Glia. (2013) 61:420-31. doi: 10.1002/glia.22445

78. Srivastava DP, Evans PD. G-protein oestrogen receptor 1: trials and tribulations of a membrane oestrogen receptor. J Neuroendocrinol. (2013) 25:1219-30. doi: 10.1111/jne.12071

79. Broselid S, Berg KA, Chavera TA, Kahn R, Clarke WP, Olde B, et al. G protein-coupled receptor 30 (GPR30) forms a plasma membrane complex with membrane-associated guanylate kinases (MAGUKs) and protein kinase A-anchoring protein 5 (AKAP5) that constitutively inhibits cAMP production. J Biol Chem. (2014) 289:22117-27. doi: 10.1074/jbc.M114. 566893
80. Gaudet HM, Cheng SB, Christensen EM, Filardo EJ. The G-protein coupled estrogen receptor, GPER: the inside and inside-out story. Mol Cell Endocrinol. (2015) 418 (Pt 3):207-19. doi: 10.1016/j.mce.2015.07.016

81. Spary EJ, Chapman SE, Sinfield JK, Maqbool A, Kaye J, Batten TF. Novel $G$ protein-coupled oestrogen receptor GPR30 shows changes in mRNA expression in the rat brain over the oestrous cycle. Neurosignals. (2013) 21:14-27. doi: 10.1159/000333296

82. Woolley CS, McEwen BS. Estradiol mediates fluctuation in hippocampal synapse density during the estrous cycle in the adult rat. J Neurosci. (1992) 12:2549-54. doi: 10.1523/JNEUROSCI.12-07-02549.1992

83. de Castilhos J, Forti CD, Achaval M, Rasia-Filho AA. Dendritic spine density of posterodorsal medial amygdala neurons can be affected by gonadectomy and sex steroid manipulations in adult rats: a Golgi study. Brain Res. (2008) 1240:73-81. doi: 10.1016/j.brainres.2008.09.002

84. Ferri SL, Hildebrand PF, Way SE, Flanagan-Cato LM. Estradiol regulates markers of synaptic plasticity in the hypothalamic ventromedial nucleus and amygdala of female rats. Horm Behav. (2014) 66:409-20. doi: 10.1016/j.yhbeh.2014.06.016

85. Zancan M, Dall'Oglio A, Sarzenski TM, Maher MI, Garcia-Segura LM, RasiaFilho AA. Glial and axonal perikaryal coverage and somatic spines in the posterodorsal medial amygdala of male and cycling female rats. J Comp Neurol. (2015) 523:2127-37. doi: 10.1002/cne.23782

86. Bender RA, Zhou L, Vierk R, Brandt N, Keller A, Gee CE, et al. Sex-dependent regulation of aromatase-mediated synaptic plasticity in the basolateral amygdala. J Neurosci. (2017) 37:1532-45. doi: 10.1523/JNEUROSCI.1532-16.2016

87. Lymer J, Robinson A, Winters BD, Choleris E. Rapid effects of dorsal hippocampal G-protein coupled estrogen receptor on learning in female mice. Psychoneuroendocrinology. (2017) 77:131-40. doi: 10.1016/j.psyneuen.2016.11.019

88. Bailey DJ, Makeyeva YV, Paitel ER, Pedersen AL, Hon AT, Gunderson JA, et al. Hippocampal aromatization modulates spatial memory and characteristics of the synaptic membrane in the male Zebra Finch. Endocrinology. (2017) 158:852-9. doi: 10.1210/en.2016-1692

89. Kim J, Szinte JS, Boulware MI, Frick KM. 17 $\beta$-Estradiol and agonism of G-protein-coupled estrogen receptor enhance hippocampal memory via different cell-signaling mechanisms. J Neurosci. (2016) 36:3309-21. doi: 10.1523/JNEUROSCI.0257-15.2016

90. Kim J, Schalk JC, Koss WA, Gremminger RL, Taxier LR, Gross KS, et al. Dorsal hippocampal actin polymerization is necessary for activation of GProtein-Coupled Estrogen Receptor (GPER) to increase CA1 dendritic spine density and enhance memory consolidation. J Neurosci. (2019) 39:9598-610. doi: 10.1523/JNEUROSCI.2687-18.2019

Conflict of Interest: The authors declare that the research was conducted in the absence of any commercial or financial relationships that could be construed as a potential conflict of interest.

Copyright (C) 2020 Llorente, Marraudino, Carrillo, Bonaldo, Simon-Areces, Abellanas-Pérez, Rivero-Aguilar, Fernandez-Garcia, Pinos, Garcia-Segura, Collado and Grassi. This is an open-access article distributed under the terms of the Creative Commons Attribution License (CC BY). The use, distribution or reproduction in other forums is permitted, provided the original author(s) and the copyright owner(s) are credited and that the original publication in this journal is cited, in accordance with accepted academic practice. No use, distribution or reproduction is permitted which does not comply with these terms. 